\title{
PENYULUHAN DIGITAL MARKETING UNTUK USAHA RUMAHAN DI KELURAHAN TANJUNG BARU KEC. KEDAMAIAN
}

\author{
Deviana Sari*1, Niar Azriya ${ }^{2}$, Adelina Anum ${ }^{3}$, Hermalena Devi $^{4}$ \\ 1,2,3,4 Universitas Sang Bumi Ruwa Jurai \\ e-mail: ${ }^{* 1}$ devianasari.18@gmail.com, ${ }^{3}$ punya.adel@ gmail.com
}

\begin{abstract}
Abstrak
Kelurahan Tanjung Baru memiliki potensi terutama untuk usaha rumahan yang belum maksimal dalam pengelolaannya. Hal ini di sebabkan dan tergambar dari tingkat intelektual masyarakat yang berpendidikan di bawah SLTP dan mayoritas penduduk kelurahan Tanjung Baru pekerjaan sebagai buruh dan sebagian warga memiliki usaha rumahan seperti pengrajin oven, pembuat kemplang, pembuat kerupuk dan pembuat tahu. Dalam meningkatkan usahannya, warga keluarahan tanjung baru belum memiliki pengetahuan terkait penjualan berbasis digital. Oleh karena itu, tujuan pengabdian ini adalah melakukan penyuluhan mengenai Digital Marketing untuk usaha rumahan di kelurahan Tanjung Baru Kec. Kedamaian. Metode yang digunakan dalam kegiatan pelatihan ini adalah metode ceramah dan diskusi. Metode ceramah digunakan oleh pemateri unuk menjelaskan materi yang berkaitan dengan materi pengelolaan keuangan koperasi. Selanjutkan dilakukan diskusi untuk memperdalam materi bahasan baik bentuk tanya jawab secara perorangan maupun perwakilan peserta. Hasil pengabdian menunjukkan antusiasme yang sangat tinggi dari peserta yang merupakan para pelaku usaha rumahan di kelurahan Tanjung Baru. Hal itu ditunjukkan dengan adanya banyak pertanyaan yang diajukan peserta terkait prosedur pembuatan akunakun di platform market place dan narasumber berusaha untuk menjawab pertanyaan-pertanyaan tersebut dan memberikan penjelasan yang mendalam mengenai topik yang ditanyakan.
\end{abstract}

Kata kunci: Penyuluhan, Digital Marketing, Usaha Rumahan

Abstract

Tanjung Baru Village has potential, especially for home-based businesses that have not been optimally managed. This is caused and illustrated by the intellectual level of the community with education below junior high school and the majority of the population of Tanjung Baru village work as laborers and some residents have home businesses such as oven craftsmen, kemplang makers, crackers and tofu makers. In improving their business, Tanjung Baru residents do not yet have knowledge related to digital-based sales. Therefore, the purpose of this service is to provide counseling about Digital Marketing for home businesses in the Tanjung Baru village, Kedamaian District. The method used in this training activity is the lecture and discussion method. The lecture method is used by the presenters to explain material related to cooperative financial management materials. This was followed by a discussion to deepen the material, both in the form of individual questions and answers and representatives of participants. The results of the service showed very high enthusiasm from the participants who were home-based business actors in the Tanjung Baru village. This was shown by the many questions asked by participants regarding the procedure for creating accounts on the market place platform and the resource persons trying to answer these questions and provide in-depth explanations of the topics asked.

Keywords: Counseling, Digital Marketing, Home Business

\section{PENDAHULUAN}

Keberadaan dari Usaha Rumahan itu sendiri merupakan sebagai salah satu alternatif permasalahan penuntasan kemiskinan [1], meningkatkan pendapatan dan kesejahteraan warga desa [2]. Melalui pemberdayaan usaha rumahan ini telah terbukti memiliki daya tahan yang relatif kuat terlebih di masa pandemi Covid19, dan sudah terbukti banyak bermunculan usaha 
rumahan dan UMKM. Masyarakat Tanjung Baru memiliki banyak potensi terkait kegiatan usaha rumahan dan UMKM seperti pengarajin oven, pembuat kemplang, pembuat kerupuk dan pembuat tahu namun kegiatannya belum berjalan maksimal terlebih di era globalisasi ini. Tim Pengabdian dari Universitas Sang Bumi Ruwa Jurai mendapati permasalahan utama terkait peningkatan penjualan yang dihadapi oleh usaha rumahan dan UMKM di kelurahan Tanjung Baru yakni: kurangnya pengetahuan atas teknologi produksi dan quality control yang disebabkan minimnya kesempatan untuk mengikuti perkembangan teknologi serta kurangnya pendidikan dan pelatihan. Kurangnya pengetahuan akan pemasaran, yang disebabkan oleh terbatasnya informasi yang dapat dijangkau oleh usaha rumahan mengenai pasar yang seharusnya sangat mudah untuk diakses [3] di era revolusi 4.0 terutama dalam digital marketing yang membantu mereka dalam melakukan promosi dan memasarkan produk mereka dengan efektif [4]. Tim Pengabdi dari Universitas Sang Bumi Ruwa Jurai juga mendapati permasalahan terkait keterbatasan kemampuan usaha rumahan untuk menyediakan produk/ jasa yang sesuai dengan keinginan pasar [5], belum memaksimalkan keterbatasan sumber daya manusia [6] serta kurangnya sumber daya untuk mengembangkan SDM [7].

Umumnya pengelolaam small-business memerlukan 1) studi kelayakan, penelitian pasar, analisis perputaran uang tunia/kas, serta berbagai penelitian lain yang diperlukan suatu aktivitas bisnis [8]. 2) Tidak memiliki perencanaan sistem jangka panjang, sistem akutansi yang memadai, anggaran kebutuhan modal, struktur organisasi dan pendelegasian wewenang, serta alat-alat kegiatan manajerial lainnya (perencanaan pelaksanaan serta pengendalian usaha) yang umumnya diperlukan oleh suatu perusahaan bisnis yang profit oriented [9]. Informasi bisnis juga sangat penting untuk meningkatkan usaha dan mamaksimalkan penjualan produk, dan tidak diperkenakan hanya mengacu pada instuisi dan ambisi pengelola, serta lemah dalam promosi [10]. Usaha rumahan juga harus memahami bahwa petunjuk pelaksanaan teknis operasional kegiatan dan pengawasan mutu hasil kerja dan produk sangat penting, dan harus konsisten dengan ketentuan order/pesanan, agar tidak mengakibatkan klaim atau produk ditolak oleh pasar [11].

Setelah melakukan survey di lokasi, didapati bahwa Sumber Daya Manusia pada kelurahan Tanjung Baru belum memiliki potensi yang maksimal dan hal ini dapat tergambar dari tingkat intelektual masyarakat yang berpendidikan di bawah SLTP, mayoritas penduduk kelurahan Tanjung Baru pekerjaan sebagai buruh, dan sebagian warga memiliki usaha rumahan seperti pengarajin oven, pembuat kemplang, pembuat kerupuk dan pembuat tahu. Oleh karena itu, usaha rumahan ini sangat berpotensi dalam meningkatkan ekonomi warga apabila dikelola dengan baik. 
Home Industri adalah suatu unit usaha/perusahaan dalam skala kecil yang bergerak dalam bidang industri tertentu [12]. Biasanya perusahaan ini hanya menggunakan satu atau dua rumah sebagai pusat produksi, administrasi dan pemasaran sekaligus secara bersamaan [13]. Bila dilihat dari modal usaha dan jumlah tenaga kerja yang diserap tentu lebih sedikit daripada perusahaan-perusahaan besar pada umumnya [14].

Digital marketing adalah penggunaan internet dan penggunaan teknologi interaktif lain untuk membuat dan menghubungkan dialog antara perusahaan dan konsumen yang telah teridentifikasi [15]. Beberapa hal yang mempengaruhi Digital Marketing sebagai berikut: Website, Blog, dan e-Marketing [16]. Emarketing lebih luas dari e-commerce karena itu tidak terbatas pada transaksi antara organisasi dan stakeholders, tetapi mencakup semua proses yang berkaitan dengan pemasaran [17]. Dan yang terakhir adalah media sosial seperti Facebook, Youtube, Instagram, dan Twitter yang saat ini di minati semua kalangan terutama dalam memasarkan produk-produk dan jasanya [18].

Berdasarkan pemaparan di atas mengenai pentingnya Digital Marketing untuk usaha rumahan, maka pengabdian ini bertujuan untuk melakukan penyuluhan mengenai Digital Marketing untuk usaha rumahan di kelurahan Tanjung Baru Kec. Kedamaian.

\section{METODE}

Metode yang digunakan dalam kegiatan pelatihan ini adalah metode ceramah dan diskusi. Sasaran kegiatan program pengabdian masyarakat melalui metode penyuluhan yang akan diselenggarakan adalah warga kelurahan Tanjung baru yang menjadi pelaku usaha rumahan seperti pengrajin oven, pembuat tahu, pembuat kemplang dan pembuat kerupuk yang berjumlah 14 orang. Metode ceramah digunakan oleh pemateri unuk menjelaskan materi yang berkaitan dengan materi pengelolaan keuangan koperasi. Selanjutkan dilakukan diskusi untuk memperdalam materi bahasan baik bentuk tanya jawab secara perorangan maupun perwakilan peserta.

Rangkaian Kegiatan Pengabdian kepada masyarakat dilaksanakan selama 1 bulan yakni bulan April 2021 bertempat di Kelurahan Tanjung Baru yang dimulai dari penyusunan proposal, persiapan dan perencanaan, serta pelaksanaan penyuluhan sampai dengan laporan. Pelaksanaan kegiatan penyuluhan dilakasanakan dalam 1 hari.

Tahap Pertama, Tim Pengabdi memberikan kuisioner terkait materi untuk mengetahui seberapa jauh pemahaman peserta terkait digital marketing. Tahap kedua, Tim Pengabdi melihat hasil dari kuisioner, dan memulai memberikan materi sesuai tingkat pengetahuan peserta. Tahap Ketiga, memberikan ilutrasi dalam praktik nyata di pasar digital dengan memberi contoh platform-platform yang 
saat ini banyak digunakan oleh pelaku usaha seperti Shopee, Tokopedia, Instagram, Website dan Facebook. Tahap keempat, melakukan diskusi dan sharing terkait materi serta pendampingan dalam membuat akun di dalam platform yang dipilih oleh peserta. Tahap terakhir, memberikan kusioner yang sama untuk mengevalusi dan mengetahui sejauh mana pemehaman peserta setelah penyuluhan.

\section{HASIL DAN PEMBAHASAN}

Hasil dari kegiatan pengabdian kepada masyarakat ini diantaranya meningkatkan pengetahuan dan pemahaman tentang digital marketing, hal ini dapat dilihat dari pengamatan, diskusi dan tanya jawab selama proses penyuluhan dan kembalinya kuisioner yang diisi peserta setelah kegiatan. Kegiatan ini sukses dalam meningkatkan keterampilan warga tanjung baru yang berperan penting sebagai pelaku usaha rumahan, hal ini dapat dilihat dari kemampuan peserta dalam mebuat akun-akun media sosial dan membuat mini konten untuk produknya, dan warga berhasil memasarkan produknya di salah satu platform shopee.

Pada kegiatan penyuluhan yang telah dilaksanakan juga menunjukkan antusiasme yang sangat tinggi dari peserta yang merupakan para pelaku usaha rumahan di kelurahan Tanjung Baru. Hal itu ditunjukkan dengan adanya banyak pertanyaan yang diajukan peserta terkait prosedur pembuatan akun-akun di platform market place dan narasumber berusaha untuk menjawab pertanyaan-pertanyaan tersebut dan memberikan penjelasan yang mendalam mengenai topik yang ditanyakan.

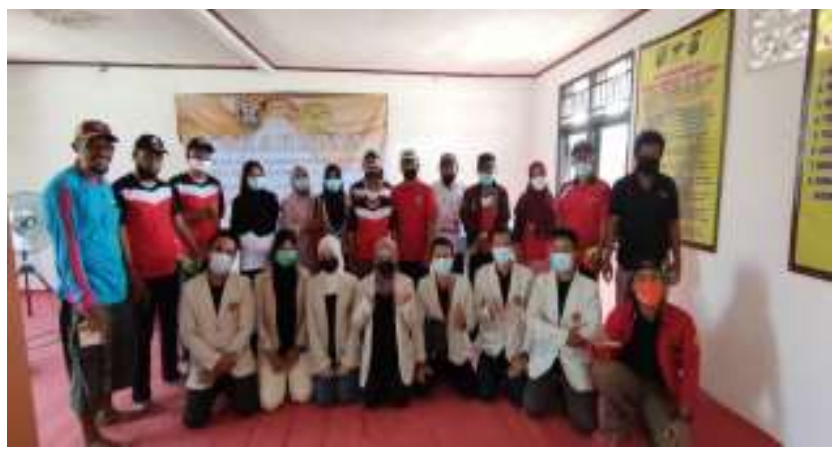

Gambar 1. Foto Bersama dengan Peserta

Setelah dilakukan kegiatan pengabdian, ditemukan pula Faktor penghambat kegiatan yakni beberapa peserta tidak memiliki e-mail resmi sehingga para pengabdi membantu dalam membuatkan satu persatu e-mail milik mereka. Selain itu, sebagian sudah memiliki media sosial namun belum meregistrasikan untuk menjadi akun bisnis. Peserta juga masih sulit memahami terkait market place, sulit melakukan upload ke beberapa akun sebagai penjual dikarenakan terlalu banyak bagian-bagian yang harus diisi dan peserta harus mengisi terlebih dahulu secara detail terkait produk yang akan di jual. Beberpa hal tersebut memakan waktu yang cukup lama karena terkait jaringan internet yang harus stabil.

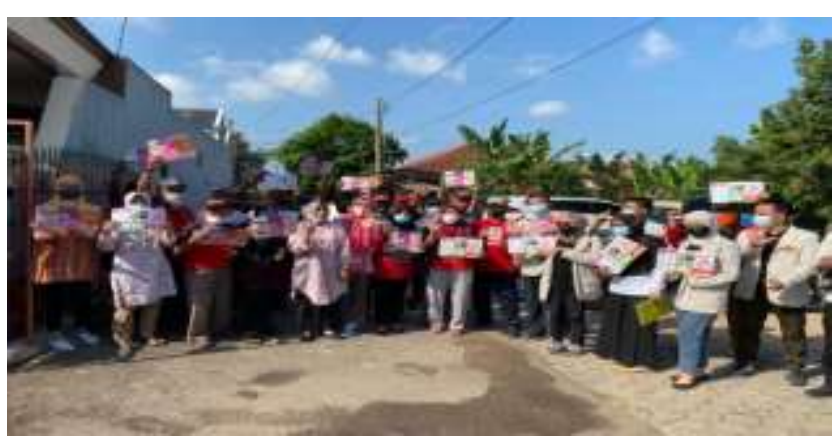

Gambar 2. Foto Pengabdi Bersama Peserta 
UCAPAN TERIMA KASIH

Dalam Kesempatan kali ini, saya ucapkan terima kasih kepada Dekan Fakultas Ekonomi, yang telah memberikan izin kepada tim pengabdian Fakultas Ekonomi dalam melaksanakan kegiatan pengabdian kepada masyarakat. Pejabat di Lingkungan Kecamatan Kedamaian dan Kelurahan Tanjung Baru yang telah memberikan kami kesempatan untuk melaksanakan kegiatan pengabdian, dan Rekanrekan tim dosen dan mahasiswa Fakultas Ekonomi sebagai pelaksana kegiatan pengabdian kepada masyarakat di lapangan yang telah melaksanakan kegiatan ini dengan baik.

\section{DAFTAR PUSTAKA}

[1] A. Djabbar, J. Rizal, and E. N. Rizaly, "Dampak Keberadaan Sektor Pariwisata Terhadap Kehidupan Sosial Ekonomi Masyarakat Home Creative 'Lentera Donggo' Kecamatan Soromandi Bima NTB," JPPMP J. Penelit. dan Pengabdi. Masy. Bid. Pariwisata, vol. 1, no. 1, pp. 1420, 2021, [Online]. Available: http://journal.ainarapress.org/index.php/jpp mp/article/view/58.

[2] E. Murti and H. Harianto, "Pendekatan One Village One Produk (OVOP) Dalam Pemberdayaan Ekonomi Desa,” 2019, [Online]. Available: https://jurnalfti.unmer.ac.id/index.php/sena sif/article/view/244.

[3] I. S. Machfiroh, "Strategi dan Dampak Kenaikan Harga Kedelai Terhadap Laba Usaha Produsen Tempe di Desa Panggung," J. Hum. Teknol., vol. 5, no. 2, pp. 1-7, 2019, doi: 10.34128/jht.v5i2.56.

[4] M. T. Febriyantoro and D. Arisandi, "Pemanfaatan Digital Marketing Bagi Usaha Mikro, Kecil Dan Menengah Pada Era Masyarakat Ekonomi Asean," JMD J. Ris. Manaj. Bisnis Dewantara, vol. 1, no. 2, pp. 61-76, 2018, doi: 10.26533/jmd.v1i2.175.

[5] E. Mahanani, "Telaah Strategi Pemasaran: Upaya Meningkatkan Daya Saing Pasar Bisnis Online Di Masa Pandemi Covid-19," J. Manaj. dan Perbank., vol. 8, no. 2, pp. 26-36, 2021, [Online]. Available: http://repository.upi-yai.ac.id/4250/.

[6] W. A. Saputro and R. N. Ningrum, "Pergeseran Penguatan Sumber Daya Manusia Di Sektor Yang Minimal Dampaknya Terhadap Pandemi Covid-19," J. Agribussines, Soc. Econ., vol. 1, no. 1, pp. 1-11, 2021.

[7] M. Sholahuddin, "Tantangan Perbankan Syariah Dalam Peranannya Mengembangkan UMKM," Semin. Nas. Call Pap. SANCALL, pp. 496-500, 2013, [Online]. Available: https://publikasiilmiah.ums.ac.id/bitstream/ handle/11617/3796/48. M. Sholahuddin.pdf?sequence $=1$. 
[8] I. Y. Niode, "Sektor UMKM di Indonesia: Profil, Masalah dan Strategi Pemberdayaan," J. Kaji. Ekon. dan Bisnis OIKOS-NOMOS, vol. 2, no. 1, pp. 1-10, 2009, [Online]. Available: https://repository.ung.ac.id/kategori/show/ uncategorized/9446/jurnal-sektor-umkmdi-indonesia-profil-masalah-dan-strategipemberdayaan.html.

[9] L. R. Naufalin, "Tantangan pengembangan usaha mikro kecil menengah (umkm) di kabupaten banyumas," J. Ekon. Bisnis dan Akunt., vol. 22, no. 1, pp. 95-102, 2020.

[10] Mardiah, M. Suprayatmi, D. Gemina, and A. Rahayu, "Strategi Meningkatkan Daya beli Masyarakat Melalui Iptek Bagi Masyarakat Petani Rosela," Media Pengabdi. Kpd. Masy. Qardhul Hasan, vol. 1, no. 1, pp. 11-32, 2015.

[11] H. Rodiah, "Pengaruh Labelisasi Halal Terhadap Usaha Roti Tawar di Kec. Bagan Sinembah Kab. Rokan Hilir di Tinjau Menurut Perspektif Ekonomi Islam," Universitas Islam Negeri Sultan Syarif Kasim Riau, 2013.

[12] Diana and N. Laila, "Strategi Pengembangan Usaha Home Industri Makanan Sebagai Peluang Pendapatan di masa Pandemi Covid 19," Pros. Semin. Nas. Pengabdi. Masy. LPPM UMJ, vol. 1, no. 1, pp. 1-8, 2020, [Online]. Available: http://jurnal.umj.ac.id/index.php/semnaskat
[13] A. F. Pebriyanto et al., "Distribusi Binomial Sebagai Pengukuran Keberhasilan dan Kegagalan Produksi Home Industri@One Hand Made," Bull. Appl. Ind. Eng. Theory, vol. 2, no. 2, pp. 94-98, 2021.

[14] N. Nurmiasih, "Peningkatan Kesejahteraan Keluarga Industri Kecil Kue Cucur di Desa Giricahyo Kecamatan Panggang Kabupaten Gunungkidul Yogyakarta," J. Kel., vol. 2, no. 1, pp. 22-30, 2016.

[15] A. T. Haryanto and S. N. Dewi, "Strategi Pengembangan Digital Marketing, Orientasi Ekuitas Merk, Marketing Intermediaris dan Kinerja Pemasaran di Perbankkan Syariah," J. Ilm. Ekon. Islam, vol. 6, no. 2, p. 163, 2020, doi: 10.29040/jiei.v6i2.1065.

[16] R. Abdu, "Pengaruh Digital Marketing Terhadap Corporate Image Pada PT AHM di Kota Bandung Tahun 2017," $e$ Proceeding Appl. Sci., vol. 4, no. 2, pp. 321-332, 2018.

[17] D. D. Hanggara, "Perancangan, Pengimplementasian dan Evaluasi Strategi Pemasaran serta Penerapan E-Marketplaces Pada UKM PJ Collection,” Institut Bisnis dan Informatika Stikom Surabaya, 2019.

[18] D. Sarastuti, "Strategi Komunikasi Pemasaran Online Produk Busana Muslim Queenova," Visi Komun., vol. 16, no. 1, pp. 71-90, 2017, [Online]. Available: www.queenova.com,. 